FACTA UNIVERSITATIS

Series: Physical Education and Sport, Vol. 17, No 2, 2019, pp. 167 - 179

https://doi.org/10.22190/FUPES190530018F

Research article

\title{
NEUROMUSCULAR CHARACTERISTICS OF THE BICEPS FEMORIS MUSCLE IN THE TOP SERBIAN SOCCER PLAYERS MEASURED BY THE TENSIOMYOGRAPHY METHOD: A QUANTITATIVE MODEL
}

\author{
UDC 796.332:616.747 \\ 796:611.98
}

\author{
Miloslav Fabok ${ }^{1}$, Bojan Leontijević ${ }^{2}$, Lazar Tomić ${ }^{2}$, Milivoj Dopsaj ${ }^{2,3}$ \\ ${ }^{1}$ Diagnostic - Training Center “Advance Fitness", Belgrade, Serbia \\ ${ }^{2}$ Faculty of Sport and Physical Education, University of Belgrade, Belgrade, Serbia \\ ${ }^{3}$ Institute of Sport, Tourism and Service, South Ural State University, Chelyabinsk, Russia
}

\begin{abstract}
The main aim of this study was to define the quantitative neuromuscular characteristics of the Biceps Femoris muscle $(B F)$ as the knee joint flexor, i.e. the major synergist of the caudal body in all specific movement tasks of a football player, measured by the tensiomyography (TMG) method. The secondary aim of the study was to compare all $T M G-B F$ characteristics in relation to bilateral dimorphism, as well as to compare dominant and non-dominant legs. The research was conducted on a sample which included 54 professional players aged $23.0 \pm 4.4$ years; body height: $182.6 \pm 15.1 \mathrm{~cm}$; body mass: $81.2 \pm$ $15.1 \mathrm{~kg}$; BMI: $23.3 \pm 1.2 \mathrm{~kg} / \mathrm{cm}^{2}$. TMG variables were measured on the muscles during a transition training phase (mid-season and end of the season). The results have shown that the average Tc $-32.19 \pm 7.64$ and $33.21 \pm 8.88 \mathrm{~ms}$, Td $-25.56 \pm 3.58$ and $25.44 \pm 3.20 \mathrm{~ms}$, and Dm $-7.39 \pm 1.87$ and $7.52 \pm 2.50 \mathrm{~mm}$, for the dominant and non-dominant leg, respectively. The results have indicated that there was no statistically significant difference between the examined TMG variables of the dominant and non-dominant leg (Wilks' lambda Value = 0.979, $F=0.300, p=0.952$, Part. $\eta^{2}=0.021$ ). It may be stated that there are no differences in the manifestation of neuromuscular characteristics in healthy elite football players regardless of their dominant leg. A high level of preparedness in football in addition to a completely healthy status of the body and locomotor system result in a complete neuromuscular contractile symmetry BF of both legs.
\end{abstract}

Key words: Tensiomyography, Football, Biceps Femoris, Muscle, Dominant leg

Received May 30, 2019/ Accepted October 04, 2019

Corresponding author: Miloslav Fabok

Diagnostic - Training Center "Advance Fitness", Pariske komune 26, Belgrade, Serbia

Phone: +381 644844422 •E-mail: fabokmiloslavdif@gmail.com 


\section{INTRODUCTION}

In modern society, football represents the most widespread and most popular activity in the field of sports, both on a professional and amateur level (Andersen, Larsen, Tenga, Engebretsen, \& Bahr, 2003), with a constant demand for performance improvement (Ostojić, 2000). According to the conducted research by Wallace \& Norton (2014), the requirements in top-level football have greatly increased over the previous period, and this especially relates to the intensity of the play itself, the strain that players are exposed to during the play and the speed at which some football skills are performed during a game, both with and without the ball. Therefore, in order to meet the requirements of the game, a modern player must possess an exceptional level of integral preparedness, i.e., harmonized physical, functional, technical and tactical as well as psychological preparedness.

The nature of the football game implies that players demonstrate various forms of movement and technique elements during their performance. The results of previous studies have shown that a player spends up to $96 \%$ the time of active play moving without the ball (walking, running, jumping, turning, stopping, etc.) (Wallace \& Norton, 2014), and that the dominant technical element that a player performs with a ball is hitting the ball (passes, shots on goal, centers, goalie's long pass, etc.) (Janković \& Leontijević, 2008). The situations when a player performs sprints, jumps, or technical elements with the ball at the maximum intensity are regarded as the moments when most of the hamstring injuries have been recorded (Arnason et al., 2004; Arnason, Gudmundsson, Dahl, \& Johannsson, 1996; Hawkins \& Fuller, 1999; Woods et al., 2004). As the frequency of the aforesaid elements of the modern football game increases with an emerging trend of general intensification of the play itself, the frequency of situations that involve an increasing risk of possible injuries to the hamstring muscles, i.e., BF muscles also increases, as considered from an epidemiological point of view (Fried \& Lloyd, 1992).

EMG analysis of the hamstring during sprints indicated the highest activity of BF muscle was observed in the stage of a forward swing when the movement is realized by an eccentric contraction of the hamstring muscles, as well as during contact with the surface when the muscle is in a transient phase of the muscular contraction i.e. stretch-shortening cycle (SSC) (Jonhagen, Ericson, Nemeth, \& Eriksson, 1996). Also, by analyzing the ball hits, it was found that the BF muscle significantly increases the activity up to $50 \%$ of the overall time before contact with the ball (Kellis, Katis, \& Gissis, 2004).

TMG is a non-invasive method that evaluates the contractile properties of the skeletal muscles (Šimunić, 2012). This measurement method has showed a high reliability and sensitivity to detecting changes in muscular reactions (Križaj, Šimunić, \& Zagar, 2008; Rey et al., 2012b) and it has also been found to possess a high reliability to measure the following variables: contraction time (Tc), half-relaxation time (Tr), delay time (Td), sustain time (Ts), and maximum radial displacement of the muscle belly (Dm) in muscles vastus medialis, vastus lateralis, rectus femoris, and BF (Rey, Lago-Peñas, \& Lago-Ballesteros, 2012a; Rey, LagoPeñas, Lago-Ballesteros, \& Casáis, 2012b; Carrasco, Sanudo, de Hoyo, Pradas, \& Da Silva, 2011; Tous-Fajardo et al., 2010). Thus, the information about muscle stiffness, contraction time, dominance and type of the muscle fiber, as well as about a potential risk that is present during the performance of a specific sports activity is obtained (Rey et al., 2012a; Alentorn-Geli et al., 2015).

The application of a TMG measuring device is widespread in sport, therefore, it has been used in determining the muscular characteristics of athletes engaged in volleyball (Dopsaj, 
Ivanović, \& Ćopić, 2014; Rodríguez-Ruiz et al., 2012), triathlon (García-Manso et al., 2011a), cycling (García-García, Cancela-Carral, Martínez-Trigo, \& Serrano-Gómez, 2013), kayak (García-García, Cancela-Carral, \& Huelin-Trillo, 2015), professional dance (Zagorc, Šimunič, Pišot, \& Oreb, 2010), football (Rey et al., 2012b; Rusu et al., 2013; Alvarez-Diaz et al., 2014), etc.

In football players, the studies mostly examined the contractile properties of muscles when exposed to cold water after loading (García-Manso et al., 2011b), during recovery (Rey et al., 2012b), in players at different positions (Rey et al., 2012a), during the recovery of the anterior cruciate ligament (Alentorn-Geli et al., 2015), when assessing the effects of different types of training (Rusu et al., 2013). It has also been found that the TMG analysis is a reliable method for identifying a lateral asymmetry between the dominant and non-dominant leg (Rodríguez-Ruiz et al., 2014).

Taking into account the limitations and different applications of TMG, the main aim of this study was to define and present the quantitative neuromuscular characteristics of the BF muscle, as one of the most important muscles of the lower extremities in football, which plays an important role in all specific football movements, on a sample of the elite Serbian football players. The secondary aim of this study was to compare TMG-BF characteristics in relation to defining the characteristics of bilateral dimorphism in regard to the aspect of the dominant and non-dominant leg. All the data obtained can also serve as the initial diagnostic norms and standards in relation to future research of this type in football.

\section{METHODS}

\section{Sample of participants}

The conducted research included a sample of a total of 54 professional football players, including 19 players who were members of the Serbian national team (U20) that won the Football World Cup in New Zealand in 2015. All the examined participants are from Serbia (19 defenders, 19 midfielders, 11 attacking and 5 goalkeepers). Most of the players indicated their right leg as the dominant one (41), while only 13 players were leftfooted. The sample of the participants possessed the following descriptive characteristics $($ mean $\pm \mathrm{SD})$ : age, $23.0 \pm 4.4$ years; body height, $182.6 \pm 15.1 \mathrm{~cm}$; body mass, $81.2 \pm$ $15.1 \mathrm{~kg}$; body mass index $(\mathrm{BMI}), 23.3 \pm 1.2 \mathrm{~kg} / \mathrm{cm}^{2}$. At the time when the testing was carried out, the players had no muscular problems i.e. without injuries during the competition break (summer and winter transition period). All of the players were informed in detail about the test conditions and the possible risks and benefits of this research. The study was approved by the Ethics Committee of the Faculty of Sport and Physical Education of the University of Belgrade (02 No. 484-2).

\section{Study design}

The testing was conducted in the "Advance Fitness" diagnostic and training center, as well as at the Faculty of Sport and Physical Education, i.e. at the Methodical Research Laboratory from 2015 to 2018. All the participants were professional players with a relatively similar competition schedule (autumn and spring season period) who appeared in the Serbian National Super League, as well as in various football clubs throughout Europe (England, Spain, Germany, Portugal, Austria, Croatia, Belgium, Norway and Hungary). On 
the day when the testing was carried out, the participants were engaged in no physical activity, i.e. had no training sessions.

\section{Testing procedure}

The TMG System (TMG-BMC Ltd., Ljubljana, Slovenia) equipped with a TransTekwGK40 sensor (GK 40, Panoptik d.o.o., Ljubljana, Slovenia) was applied to measure the neuromechanical properties of the BF muscle. An involuntary muscle stimulation was provoked by the $5 \times 5 \mathrm{~cm}$ muscle reaction self-adhesive electrodes (TMG electrodes, TMG-BMC d.o.o. Ljubljana, Slovenia) that were placed according to the manufacturer's recommendation, i.e. at a distance of 50-60mm from the digital sensor (Wilson, Johnson \& Francis, 2018).

The testing protocol was determined according to Rey et al. $\left(2012^{\mathrm{a}}\right)$. During the testing, the participants were in a prone position, with their ankles placed on a foam cushion of a specific TMG design which was used to fix the position of the knee joint at an angle of $165^{\circ}$ (Figure 1). Due to the individual anatomical differences, the sensor was positioned individually by palpation in each participant, and in accordance with the previously published protocol (Valenčić \& Đorđević, 2001). The monophasic electrical stimulation with an initial stimulus intensity of $30 \mathrm{~mA}$ was applied. Each subsequent stimulus was increased by $10 \mathrm{~mA}$ until the maximum value of the muscle belly displacement $(\mathrm{Dm})$ was reached, i.e. until the moment when there were no evident changes in the observed variables in relation to an increase in the electrical stimulation. A rest of 10 seconds was used between each stimulus in order to relax the muscle, i.e. to avoid the effect of potentiation between the stimuli (Križaj et al., 2008). The measurements were carried out by experienced examiners whereby one was responsible for managing the intensity and frequency of the applied stimulus and the other was responsible for positioning the electrodes and the sensors by which the testing was performed.

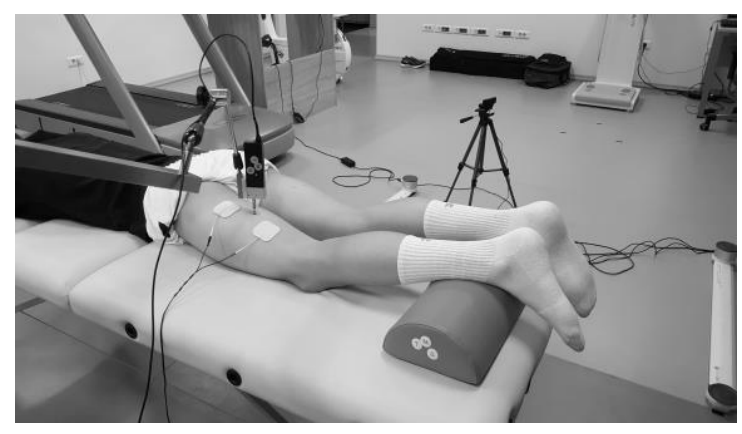

Fig. 1 Tensiomyography assessment of the biceps femoris muscle

\section{Sample of variables}

For the purposes of this study, the following variables were used to describe the functional involuntary contractile property of the examined muscle:

1. Tc - time of contraction, for dominant (Dom) and non Dominant (NonDom), expressed in milliseconds (ms), represents the time between $10 \%$ and $90 \%$ of the maximum vertical muscle movement.

2. Td - delay time, for Dom and NonDom expressed in ms, the time required to reach $10 \%$ of the maximum muscle belly displacement. 
3. $\mathrm{Tc}+\mathrm{Td}-$ total time contraction, for Dom and NonDom expressed in ms, represents the overall contraction time required for the complete muscle belly displacement.

4. $\mathrm{Tr}$ - relaxation time, for Dom and NonDom expressed in ms, represents the time required to reduce the muscle contraction, after an electrical stimulus, from $90 \%$ to $50 \%$ of the overall maximum muscle belly displacement.

5. Ts - sustain time, for Dom and NonDom expressed in ms, represents the time from $50 \%$ of the muscle contraction to $50 \%$ of its relaxation.

6. Dm - maximal displacement, for Dom and NonDom expressed in $\mathrm{mm}$, represents the overall displacement (shortening) of the muscle by an involuntary stimulation.

7. $\mathrm{Vc}$ - contraction velocity, for Dom and NonDom expressed in $\mathrm{mm} / \mathrm{ms}$, calculated as a ratio between $\mathrm{Dm}$ and $\mathrm{Tc}+\mathrm{Td}$ (Loturco et al., 2016).

\section{Statistical analysis}

All the data obtained by the testing were analyzed by the application of descriptive statistical analysis, whereby the following were calculated: parameters of central tendency - arithmetic mean; parameters of data dispersion - standard deviation (SD), coefficient of variation (cV\%), absolute and relative error in the measurement (Std. Err \& Std. Err. \%). The equality of data distribution was tested using a nonparametric Kolmogorov-Smirnov Test (K-S Z). In addition, a multivariate analysis of variance (MANOVA) as well as a univariate analysis of variance (ANOVA) were applied in order to determine the differences in the measured variables of the dominant and non-dominant leg. The statistical significance was defined at the level of probability of $95 \%$ i.e. $p=0.05$ (Hair, Black, Babin, Anderson, \& Tatham, 2006). All the data was processed using the statistical data processing software SPSS 20 (SPSS Inc., Chicago, IL, USA).

\section{RESULTS}

Table 1 presents the results of descriptive statistics $(\mathrm{Mean} \pm \mathrm{SD})$ of the examined variables (Tc, Td, Tc+Td, Tr, Dm, Vc and Ts) including the distribution parameters for the Dom and NonDom leg for the BF muscle. It can be noted that the homogeneity of the results is low, which indicates a high level of standardization of the measurement procedure. All the variables have the shape of a normal distribution at a statistically significant level, except for the variable $\mathrm{Tr}$ of the dominant $\operatorname{leg}(\mathrm{cV}=51.59 \%, \mathrm{~K}-\mathrm{S}=1.621, \mathrm{p}=0.010)$.

Table 2 shows the results of the multivariate analysis of variance (MANOVA), as well as the results of the univariate analysis of variance (ANOVA). It was found that, both at general and partial level, there are no statistically significant differences in the examined TMG variables in relation to the dominant and non-dominant leg regarding the studied sample of the football players (Wilks' lambda Value $=0.979, \mathrm{~F}=0.300, \mathrm{p}=0.952$, Part. $\eta^{2}=0.021$ ).

Figures $2 \mathrm{a} \& 2 \mathrm{~b}$ show the calculated dependency Time - Displacement as the defined quantitative neuromuscular models for the BF of both legs. The presented models provide the information on the initial standard of the neuromuscular status of the tested muscle groups and represent the first stage in defining the final TMG-BF model of the Serbian elite football players, in order to optimize the training technology in football. 
Table 1 Descriptive statistics of the studied variables with parameters of distribution

\begin{tabular}{clrrrrrrr}
\hline \multicolumn{1}{c}{ TMG variables } & Mean & SD & cV (\%) & $\begin{array}{c}\text { Std. Err. } \\
\text { (aps) }\end{array}$ & $\begin{array}{c}\text { Std. Err. } \\
\text { \% (Rel) }\end{array}$ & K-S Z & p value \\
\hline & Tc_Dom (ms) & 32.19 & 7.64 & 23.73 & 1.04 & 3.23 & 1.192 & 0.116 \\
Td_Dom (ms) & 25.56 & 3.58 & 14.01 & 0.49 & 1.92 & 0.976 & 0.296 \\
Dominant Tc+Td_Dom (ms) & 57.74 & 9.50 & 16.45 & 1.30 & 2.25 & 0.649 & 0.794 \\
Leg Bic. & Tr_Dom (ms) & 45.69 & 23.57 & 51.59 & 3.20 & 7.00 & 1.621 & 0.010 \\
Femoris & Dm_Dom (mm) & 7.39 & 1.87 & 25.30 & 0.25 & 3.38 & 0.931 & 0.351 \\
& Vc_Dom (mm/ms) & 0.129 & 0.029 & 22.48 & .004 & 3.10 & 0.629 & 0.824 \\
& Ts_Dom (ms) & 185.79 & 33.78 & 18.18 & 4.60 & 2.48 & 0.750 & 0.627 \\
\hline & Tc_Non Dom (ms) & 33.21 & 8.88 & 26.74 & 1.21 & 3.64 & 0.574 & 0.897 \\
Non & Td_Non Dom (ms) & 25.44 & 3.20 & 12.58 & 0.44 & 1.73 & 0.720 & 0.677 \\
Dominant & Tc+Td_Non Dom (ms) & 58.66 & 10.51 & 17.92 & 1.43 & 2.44 & 0.646 & 0.798 \\
Leg Bic. & Tr_Non Dom (ms) & 44.60 & 21.13 & 47.38 & 2.88 & 6.46 & 0.928 & 0.356 \\
Femoris & Dm_Non Dom (mm) & 7.52 & 2.50 & 33.24 & 0.34 & 4.52 & 0.537 & 0.936 \\
& Vc_Non Dom (mm/ms) & 0.129 & 0.040 & 31.01 & 0.005 & 3.88 & 0.776 & 0.584 \\
& Ts_Non Dom (ms) & 180.80 & 26.70 & 14.77 & 3.63 & 2.01 & 0.607 & 0.855 \\
\hline
\end{tabular}

Table 2 Results of the MANOVA - Multivariate test and ANOVA - Univariate test

\begin{tabular}{lrrrcc}
\hline \multicolumn{5}{c}{ Multivariate Test } \\
\hline Wilks' Lambda & Value & $\mathrm{F}$ & $\mathrm{p}$ value & Part. $\prod^{2}$ & Observed Power \\
\hline \multicolumn{7}{c}{$\begin{array}{c}\text { Univariate Test } \\
\text { Dependent }\end{array}$} & 0.979 & 0.300 & 0.952 & 0.021 & 0.136 \\
Variable & Sum of Squares & $\mathrm{F}$ & $\mathrm{p}$ value & Part. $\prod^{2}$ & Observed Power \\
\hline Tc & 28.05 & 0.409 & 0.524 & 0.004 & 0.097 \\
Td & 0.32 & 0.028 & 0.867 & 0.000 & 0.053 \\
Tc+Td & 22.30 & 0.222 & 0.638 & 0.002 & 0.075 \\
Tr & 31.73 & 0.063 & 0.802 & 0.001 & 0.057 \\
Dm & 0.51 & 0.105 & 0.747 & 0.001 & 0.062 \\
Vc & 9.26 & 0.000 & 0.998 & 0.000 & 0.050 \\
Ts & 671.80 & 0.725 & 0.396 & 0.007 & 0.135
\end{tabular}
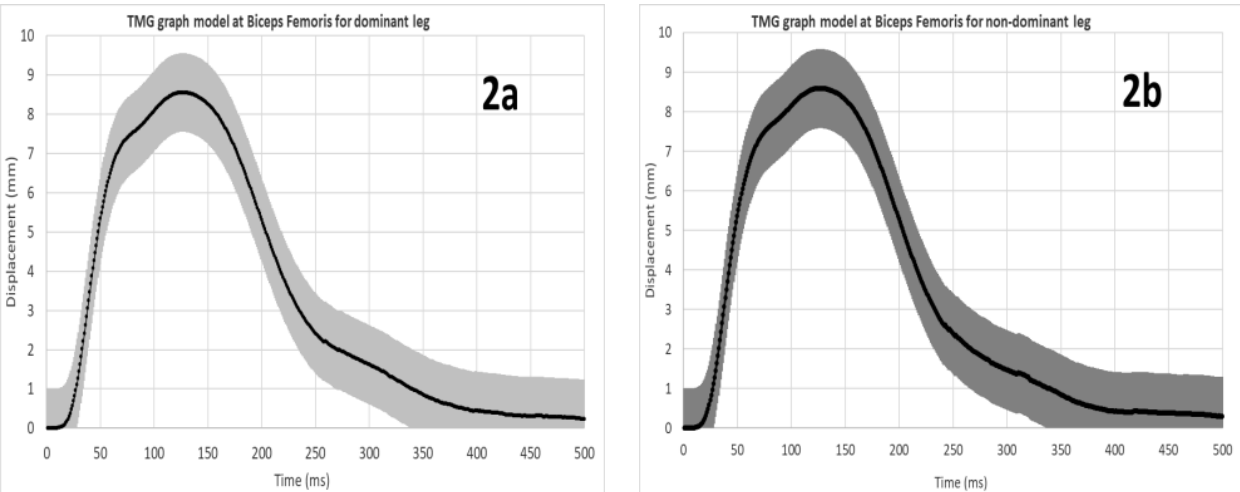

Fig. 2a \& 2b Models of Tensiomyography graphs at Biceps femoris dominant and nondominant leg 

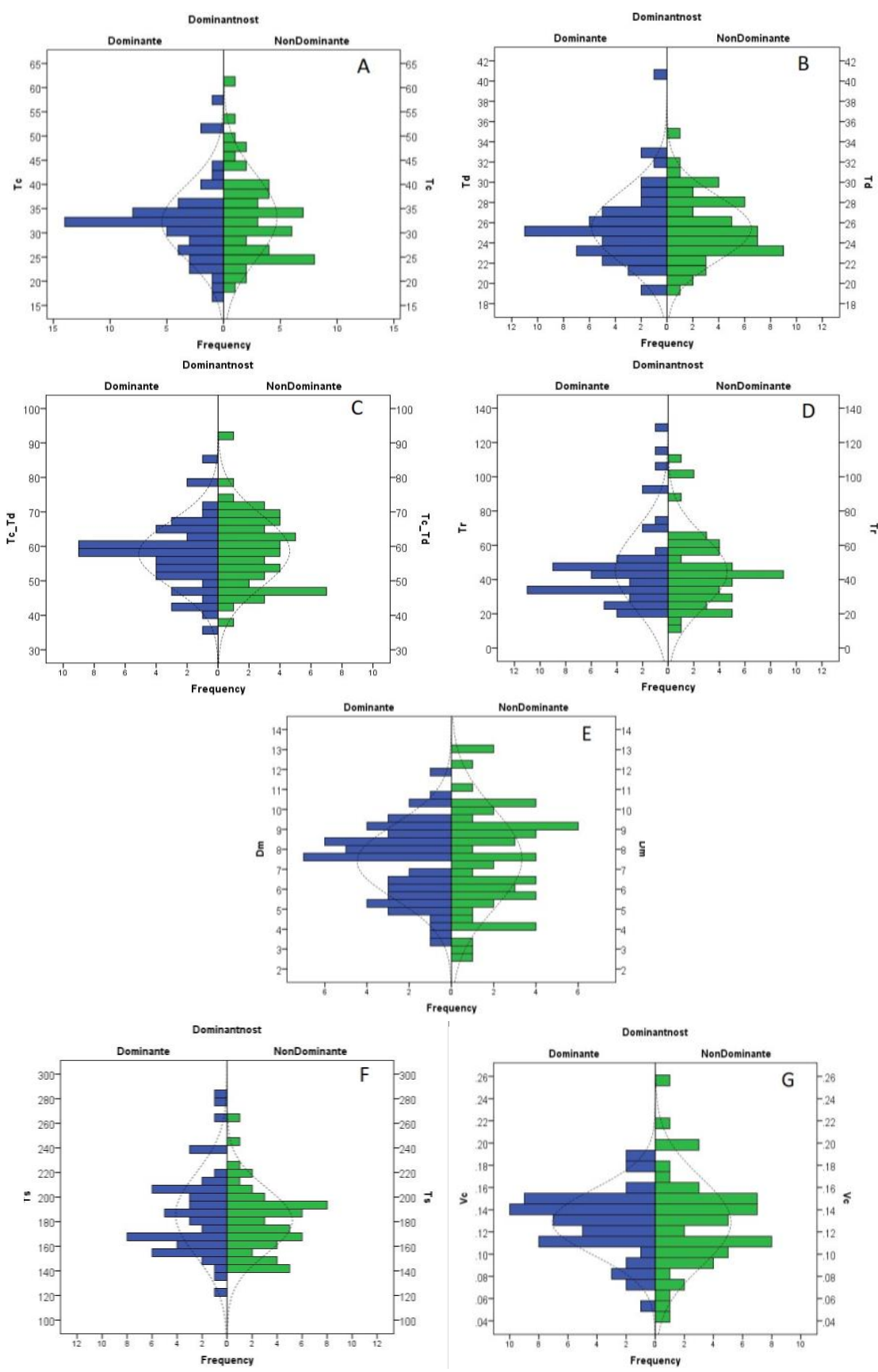

Fig. 3 Presentation of the population distributions of the results of the examined variables (Contraction time (Tc) (A), delay time (Td) (B), total time contraction (Tc+Td) (C), half relaxation time $(\mathrm{Tr})(\mathrm{D})$, maximal radial displacement $(\mathrm{Dm})(\mathrm{E})$, sustain time $(\mathrm{Ts})(\mathrm{F})$, contraction velocity $(\mathrm{Vc})(\mathrm{G}))$, in relation to the dominant and non-dominant leg 
Figure 3 shows the population distributions of the results of the examined variables of the Dom and NonDom leg. According to the presented comparative distributions, in case of the dominant leg variable Dm (E), a centralization tendency in the rigidity of the examined muscle as a system relative to the NonDom leg can be observed, which may indicate a leptokurtic distribution shape, i.e. a higher standard grouping of the given ability in the Dom leg compared to the NonDom one, where it may be noticed that a variation of the distribution of the measured muscle property is much greater, i.e. the distribution has a platycurtic distribution. Similar distribution characteristics can be recorded in the variables Vc (G) as well as the variables Tc_Td (C).

\section{DISCUSSION}

The main aim of this study was to define the differences and the quantitative neuromuscular characteristics of the BF muscle regarded as one of the most important muscles of the lower extremities, which plays an important role in football in performing sprints, jumps, passes and other movement activities, measured by the method of TMG on a sample of the Serbian elite football players. The secondary aim of the study was to define the level of bilateral dimorphism of the examined variables and to carry out an external validation of the results obtained on a population of elite Serbian footballers in relation to the existing professional standards from leading European football countries.

According to the obtained results, it has been shown that there are no statistical differences found in healthy footballers from Serbia when it comes to neuromuscular characteristics regardless of leg dominance. In other words, there is no bilateral dimorphism, as a measure of difference or lack of a specific property, found between the dominant and non-dominant leg. This, most likely, points to the fact that the tested players were well-trained according to the type of lateral symmetry and that the measured neuromuscular muscle functions were harmonized in both legs. However, it can be noted that a slightly altered distribution and less homogeneity were observed in the variable Tr of the Dom and NonDom leg, which can be recognized as information about a possible chronicity of the fatigue phenomenon which is identified by an increasing value of the variable (Križaj et al., 2008).

The modern football game abounds in game elements such as jumps, sprints and passes, which indicates an increase in the general intensification of physical and motor strains during the play itself. Also, from an epidemiological point of view, it has been determined that as the intensity of the play increases, the frequency of situations involving a risk of possible hamstring muscle injuries is also increased (Fried \& Lloyd, 1992). Furthermore, a role of the BF muscle that, in hitting the ball, increases the activity up to $50 \%$ of the overall time prior to a contact with the ball is especially emphasized (Kellis et al., 2004). Benitez Jimenez, Fernandez, Montero, \& Romacho (2013) in their research have concluded that the parameters which should be specifically focused on when using the TMG are variables Dm and Tc. This increase of Dm reduces muscle stiffness, affecting the loss of strength and explosive ability, while lower values of Dm suggest an increase in stiffness or muscle tone (Kokkonen, Nelson, \& Cornwell, 1998; Križaj et al., 2008; Rey et al., 2012b). Tc values of over 30ms clearly indicate a possible presence of slow muscle fibers in the muscle (Dahmane, Valenčić, Knez, \& Erzen, 2001), whereas the relationship between the variable Tc and the properties of the muscle fiber structure in sprinters is at a high statistically significant level (Dahmane, Đorđević, Smerdu, 2006). 
Generally, the two variables are the most reliable and most stable parameters for monitoring the functional state of neuromuscular characteristics of the contractile property of the measured muscle, while the less sensitive parameters are Tr and Ts (Križaj et al., 2008; Šimunič, 2012; Tous-Fajardo et al., 2010; Ditroilo, Smith, Fairweather, \& Hunter, 2013).

The results of this study have shown that no statistically significant difference was found between the measured TMG variables of the BF of the Dom and Non-Dom leg (Table 2, Wilks' Lambda Value $=0.979, \mathrm{p}=0.952$ ), nor was a partial statistically significant difference determined between the individual variables (Table $2, \mathrm{Vc}-\mathrm{p}=0.998$ do Ts $-\mathrm{p}=0.396$ ). However, although the differences have not been determined, it should be pointed out that the variables Ts and Tc have shown a slightly higher level of sensitivity in relation to defining the potential differences in the studied area (Tabela 2, Ts - Part. $\rceil 2=0.007$ i.e. $7 \%$, and Tc - Part. $\eta 2=0.004$ i.e., $4 \%$ ), therefore, more attention should be paid to it in future research.

The results obtained in the conducted research coincide with the majority of the results from the previous studies conducted on a sample of international football players (Alvarez-Diaz et al., 2014; García-García, Serrano-Gómez, \& Cuba-Dorado, 2014; García-García, SerranoGómez, Hernández-Mendo, \& Morales-Sánchez, 2017; Gil et al., 2015) in which the authors have also concluded that there are no statistically significant differences in the measured TMG variables $\mathrm{BF}$ of the Dom and NonDom leg. Also, very similar descriptive results of the examined variables were obtained on a sample of futsal (Sánchez-Sánchez et al., 2018), volleyball players (Rodríguez-Ruiz et al., 2012) and cyclists (García-García et al., 2013) in regard to the studied $\mathrm{BF}$ muscle.

In their research of the BF muscle, Alvarez-Diaz et al. (2014) found a statistically significant difference only for the variable Ts $(214.4 \pm 81.6$ vs. $195.3 \pm 64 \mathrm{~ms}$, for Dom and NonDom leg, respectively). These values are higher in relation to the results of our study from the aspect of the examined variables (Table $1,185.79 \pm 33.78$ vs. $180.80 \pm 26.70 \mathrm{~ms}$, i.e. $15.40 \%$ vs. $8.13 \%$ lower values, for Dom and NonDom leg, respectively), which may suggest a higher level of fatigue of the participants during the testing in the aforementioned study. In a study conducted by García-García et al. (2017) the mean values (dominant and non-dominant leg), of the Tc variable, were $34.5 \pm 6.6 \mathrm{~ms}$, and for variable Dm they were $7.0 \pm 1.7 \mathrm{~mm}$, which is higher by Tc and lower by Dm in relation to our study. One of the possible reasons for the mentioned findings and differences in relation to the results of this study can be explained by an interpretation of testing the sample of football players of a different level of competition, application of tests in a different training period, as well as the size and structure of the sample.

García-Manso et al. $\left(2011^{\mathrm{a}}\right)$ examined the average TMG values of the BF muscle parameters for both legs in the triathlon athletes before and after a competitive activity. The results obtained were higher for all the observed variables before the performance of the competitive activity, compared to the results obtained in our research (triathlon athletes $=65.1$ $\pm 22.1 \mathrm{~ms}, 10.8 \pm 3.5 \mathrm{~mm}, 44.1 \pm 5.4 \mathrm{~ms}, 436.8 \pm 68.1 \mathrm{~ms}, 124.6 \pm 33.8 \mathrm{~ms}$, i.e. higher by $99.10 \%, 44.77 \%, 72.94 \%, 138.30 \%, 175.97 \%$, respectively for Tc, Dm, Td, Ts, Tr). Such great differences are most likely an overall consequence of several factors, including the following: triathlon is a sport of endurance which has a different type of training load, according to continuous aerobic endurance, the selection system of triathlon athletes also includes individuals of a different type of muscle fiber compared to football players, there is a different type of fatigue present, etc.

The lower values of the variables Tc and Dm were determined in the cyclists during the competition season (García-García et al., 2013) compared to the results obtained in our study. 
Such findings may indicate that it is most likely due to a different type of motor strain, where cyclists show a high level of pedaling rate as well as a higher level of successive contractile activation and co-activation of the leg muscles, in a constant concentric and eccentric muscular mode, which is one of the more pronounced adaptations of the muscular system, which can lead to an increase of the degree of the muscle system stiffness, or an increased muscle tone.

Regarding the results obtained in non-athletes (Toskić, Dopsaj, Koropanovski, \& Jeknić, 2016) it has been determined that their values were higher in Tc, and lower in the Dm variable in relation to our study. The results have indicated that there is a greater muscle stiffness determined in the recreational players, as well as a longer time required for the realization of the $90 \%$ complete muscle contractions. In other words, a higher muscle tone (lower Dm) and a longer motor response to the overall muscle contraction (higher Tc) were observed. The most probable reason for such findings can be explained by a greater extent of sedentary time spent during the day in addition to the likely insufficient and professionally non-programmed occasional physical activities of the non-athletes.

Due to an insufficient number of relevant studies in Serbia about this, the research, which would include characteristics and differences of the examined TMG variables in relation to the positions in the game, such studies should be carried out in the future, in relation to different ages and sex, as well as in relation to different levels of competition in the football players in the Republic of Serbia.

Additionally, in regard to the further research on this topic, and in order to obtain standards for the given results, it is necessary to define the criteria of the research sample in relation to: the defined training period, i.e. the time period of testing, in relation to different orientation of the training effects, as well as in relation to the cumulative effects of different models and the cycle of training or competition load.

The results obtained in this study can serve as the initial norms and standards in defining the final TMG model of the elite football players from Serbia, which will be of significance in the future during the creation of training load, as well as in the prevention of the risk of injury. The neuromuscular profile of a football player can help coaches and medical staff to identify the initial norms that are relevant in the training, planning and programming as well as during the recovery process in each individual player. Also, in the competition cycle, the results can contribute to the assessment of a specific effect of the training on the muscle itself, by which each training unit can clearly be managed and more precisely directed.

\section{CONCLUSION}

The results have shown that there are no statistically significant differences found in healthy elite football players from the Republic of Serbia in regard to the neuromuscular characteristics measured by the method of tensiomyography, for the BF muscle regardless of the leg dominance. These findings have indicated that the players were well-trained according to the type of lateral symmetry and that the function of the muscle itself was harmonized in both the dominant and non-dominant legs. All the data obtained can also be used as the initial diagnostic norms in relation to the future research of this type, which will be of importance and relevance in the practical application in the field of football. 
Acknowledgement: This research was done as part of the project of the Ministry of Science of the Republic of Serbia, no III47015: Effects of applied physical activity on locomotor, metabolic, psycho-social and educational status of the school population in the Republic of Serbia.

\section{REFERENCES}

Alentorn-Geli, E., Alvarez-Diaz, P., Ramon, S., Marin, M., Steinbacher, G., Boffa, J., Cuscó, X., et al. (2015). Assessment of neuromuscular risk factors for anterior cruciate ligament injury through tensiomyography in male soccer players. Knee Surgery, Sports Traumatology, Arthroscopy, 23(9), 2508-2513.

Alvarez-Diaz, P., Alentorn-Geli, E., Ramon, S., Marin, M., Steinbacher, G., Rius, M., et al. (2014). Comparation of tensiomyographic neuromuscular characteristics between muscles of the dominant and non-dominant lower extremity in male soccer players. Knee Surgery Sports Traumatology Arthroscopy, 24(7), 2259-2263.

Andersen, T.E., Larsen, Ø., Tenga, A., Engebretsen, L., \& Bahr, R. (2003). Football incident analysis: a new video based method to describe injury mechanisms in professional football. British Journal of Sports Medicine, 37 (3), 226-232.

Arnason, A., Gudmundsson, A., Dahl, H.A., \& Johannsson, E. (1996). Soccer injuries in Iceland. Scandinavian Journal of Medicine \& Science in Sports, 6 (1), 40-45.

Arnason, A., Sigurdsson, SB., Gudmundsson, A., Holme, I., Engebretsen, L., \& Bahr, R. (2004). Risk factors for injuries in football. The American Journal of Sports Medicine, 32 (1 Suppl), 5S-16S.

Benitez Jimenez, A., Fernandez R.K., Montero, D.J., \& Romacho, C.J. (2013). Reliability of tensiomyography (TMG) as a muscle assessment tool. Revista Internacional de Ciencias de la Actividad Física y del Deporte, 13(52), 647-656.

Carrasco, L., Sanudo, B., de Hoyo, M., Pradas, F., \& Da Silva, M.E. (2011). Effectiveness of low-frequency vibration recovery method on blood lactate removal, muscle contractile properties and on time to exhaustion during cycling at $\mathrm{VO}_{2}$ max power output. European Journal of Applied Physiology, 111(9), 2271-2279.

Dahmane, R., Đorđević, S., \& Smerdu, V. (2006). Adaptive potential of human biceps femoris muscle demonstrated by histochemical, immunohistochemical and mechanomyographical methods. Medical \& Biological Engineering \& Computing, 44 (11), 999-1006.

Dahmane, R., Valenčić, V., Knez, N., \& Erzen, I. (2001). Evaluation of the ability to make noninvasive estimation of muscle contractile properties on the basis of the muscle belly response. Medical \& Biological Engineering \& Computing, 39, 51-55.

Ditroilo, M., Smith, IJ., Fairweather, M.M., \& Hunter, A.M. (2013). Long-term stability of tensiomyography measured under different muscle conditions. Journal of Electromyography and Kinesiology, 23 (3), 558-563.

Dopsaj, M., Ivanović, J., \& Ćopić, N. (2014). Voluntary vs non-voluntary muscle contraction explosivity: RFD vs RMTD as a possible new TMG parameter. In TMG: Today and Future, International society of tensiomiography (pp. 5-10). Rome: ISOT.

Fried, T., \& Loyd, G. J. (1992). An overview of common soccer injuries: management and prevention. Sports Medicine, 14 (4), 269-275.

García-García, O., Cancela-Carral, J.M., Martínez-Trigo, R., \& Serrano-Gómez, V. (2013). Dffierences in the contractile properties of the knee extensor and fexor muscles in professional road cyclists during the season. Journal of Strength \& Conditioning Research, 27 (10), 2760-2767.

García-García, O., Cancela-Carral, J.M., \& Huelin-Trillo, F. (2015). Neuromuscular profile of top-level women kayakers assessed through tensiomyography. The Journal of Strength \& Conditioning Research, 29(3), 844-853.

García-García, O., Serrano-Gómez, V., \& Cuba-Dorado, A. (2014). Evolution of the lateral symmetry of the lower limbs of professional footballers during the season. The Journal of Strength \& Conditioning Research, 28 (11), 33.

García-García, O., Serrano-Gómez, V., Hernández-Mendo, A., \& Morales-Sánchez, V. (2017). Baseline mechanical and neuromuscular profile of knee extensor and flexor muscles in professional soccer players at the start of the pre-season. Journal of Human Kinetics, 58(1), 23-34.

García-Manso, J.M., Rodríguez-Ruiz, D., Rodríguez-Matoso, D., de Saa, Y., Sarmiento, S., \& Quiroga, M. $\left(2011^{\mathrm{a}}\right)$. Assessment of muscle fatigue after an ultra-endurance triathlon using tensiomyography (TMG). Journal of Sports Sciences, 29(6), 619-625. 
García-Manso, J.M., Rodriguez-Matoso, D., Rodríguez-Ruiz, D., Sarmiento, S., de Saa, Y., \& Calderon, J. $\left(2011^{\mathrm{b}}\right)$. Effect of cold-water immersion on skeletal muscle contractile properties in soccer players. American Journal of Physical Medicine \& Rehabilitation, 90 (5), 356-363.

Gil, S., Loturco, I., Tricoli, V., Ugrinowitsch, C., Kobal, R., Abad, C., et al. (2015). Tensiomyography parameters and jumping and sprinting performance in Brazilian elite soccer players. Sports Biomechanics, 14(3), 340-350.

Hair, J., Black, B., Babin, B., Anderson, R., \& Tatham, R. (2006). Multivariate data analysis $\left(6^{\text {th }}\right.$ edition). Upper Saddle River, NJ: Prentice-Hall.

Hawkins, R.D., \& Fuller, C.W. (1999). A prospective epidemiological study of injuries in four English professional football clubs. British Journal of Sports Medicine, 33 (3), 196-203.

Janković, A., \& Leontijević, B. (2008). Struktura tehničko takmičarske aktivnosti u savremenom fudbalu (The structure of technical and competitive activities in modern soccer). Fizička kultura, 62 (1-2), 159-169. In Serbian

Jonhagen, S., Ericson, M.O., Nemeth, G., \& Eriksson, E. (1996). Amplitude and timing of electromyographic activity during sprinting. Scandinavian Journal of Medicine \& Science in Sport, 6 (1), 15-21.

Kellis, E., Katis, A., \& Gissis, I. (2004). Knee biomechanics of the support leg in soccer kicks from three angles of approach. Medicine \& Science in Sports \& Exercise, 36 (6), 1017-1028.

Kokkonen, J., Nelson, A. G. \& Cornwell, A. (1998). Acute muscle stretching inhibits maximal strength performance. Research Quarterly for Exercise and Sport, 69 (4), 411-415.

Križaj, D., Šimunić, B., \& Zagar, T. (2008). Short-term repeatability of parameters extracted fromradial displacement of muscle belly. Journal of Electromyography and Kinesiology, 18 (4), 645-651.

Loturco, I., Pereira, L.A., Kobal, R., Kitamura, K., Ramirez-Campillo, R., Vinicius, Z.,,et al. (2016). Muscle contraction velocity: A suitable approach to analyze the functional adaptations in elite soccer players. Journal of Sports Science \& Medicine, 15(3), 483-491.

Ostojić, S.M. (2000). Physical and physiological characteristics of elite Serbian soccer players. Facta Universitatis Series Physical Education and Sport, 1(7), 23-29.

Rey, E., Lago-Peñas, C., \& Lago-Ballesteros, J. (2012 ${ }^{\mathrm{a}}$ ). Tensiomyography of selected lower-limb muscles in professional soccer players. Journal of Electromyography and Kinesiology, 22 (6), 866-872.

Rey, E., Lago-Peñas, C., Lago-Ballesteros, J., \& Casáis, L. (2012b). The effect of recovery strategies on contractile properties using tensiomyography and perceived muscle soreness in professional soccer players. Journal of Electromyography and Kinesiology, 26 (11), 3081-3088.

Rodríguez-Ruiz, D., Diez-Vega, I., Rodríguez-Matoso, D., Fernández-del Valle, M., Sagastume, R., \& Molina, J.J. (2014). Analysis of the response speed of musculature of the knee in professional male and female volleyball players. Biomed Research International, 2014: 239708.

Rodríguez-Ruiz, D., Rodríguez-Matoso, D., Quiroga, M.E., Sarmiento, S., García-Manso, J.M., \& Da SilvaGrigoletto, M.E. (2012). Study of mechanical characteristics of the knee extensor and flexor musculature of volleyball players. European Journal of Sport Sciences, 12, 399-407.

Rusu, L.D., Cosma, G.G., Cernaianu, S.M., Marin, M.N., Rusu, P.F., Cioc- Nescu, D.P., et al. (2013). Tensiomyography method used for neuromuscular assessment of muscle training. Journal of NeuroEngineering and Rehabilitation, 10, 67.

Sánchez-Sánchez, J., Bishop, D., García-Unanue, J., Ubago-Guisado, E., Hernando, E., López-Fernández, J., et al. (2018). Effect of a Repeated Sprint Ability test on the muscle contractile properties in elite futsal players. Scientific Reports, 8 (1), 17284.

Šmunić, B. (2012). Between-day reliability of a method for non-invasive estimation of muscle composition. Journal of Electromyography and Kinesiology, 22 (4), 527-530.

Toskić, L., Dopsaj, M., Koropanovski, N., \& Jeknić, V. (2016). The neuromechanical functional contractile properties of the thigh muscles measured using tensiomyography in male athletes and non-athletes. Physical Culture, 70 (1), 34-45.

Tous-Fajardo, J. Moras, G., Rodríguez-Jiménez, S., Usach, R, Doutres, D.M., \& Maffiuletti, N.A. (2010). Interrater reliability of muscle contractile property measurements using non-invasive tensiomyography. Journal of Electromyography and Kinesiology, 20(4), 761-766.

Valenčić, V., \& Đorđević, S. (2001). Influence of acute physical exercise on twitch response elicited by stimulation of skeletal muscles in man. BioMedical Engineering, 2, 1-4.

Wallace, J.K., \& Norton, K.I. (2014). Evolution of World Cup soccer final games 1966 - 2010. Journal of Science and Medicine in Sport, 17 (2), 223-228.

Woods, C., Hawkins, R., Maltby, S., Hulse, M., Thomas, A., \& Hodson, A. (2004). The Football Association Medical Research Programme: an audit of injuries in professional football-analysis of hamstring injuries. British Journal of Sports Medicine, 38 (1), 36-41. 
Wilson, H.V., Johnson, M.I. \& Francis, P (2018). Repeated stimulation, inter-stimulus interval and interelectrode distance alters muscle contractile properties as measured by Tensiomyography. PLoS One, 13 (2), e0191965

Zagorc, M., \& Šimunič, B., Pišot, R., \& Oreb, G. (2010). A comparison of contractile parameters among twelve skeletal muscles of inter-dance couples. Kinesiologica Slovenica, 16(3), 57-65.

\section{NEUROMIŠIĆNE KARAKTERISTIKE BICEPS FEMORIS MIŠIĆA KOD VRHUNSKIH SRPSKIH FUDBALERA MERENE METODOM TENZIOMIOGRAFIJE: KVANTITATIVNI MODEL}

Glavni cilj ove studije bio je definisanje kvantitativnih neuromišićnih karakteristika mišića Biceps Femorisa (BF) kao pregibača zgloba kolena, odnosno glavnog sinergiste kaudalnog dela tela u svim specifičnim kretnim zadacima fudbalera, utvrđenim primenom tenziometrijske (TMG) metode. Sekundarni cilj studije predstavljao je uporedjivanje svih TMG-BF karakteristika prema bilateralnom dimorfizmu, kao $i$ uporedjivanje dominantne $i$ nedominantne noge. Istraživanje je sprovedeno na 54 profesionalna igrača starosti $23.0 \pm 4.4$ godina; visine: $182.6 \pm 15.1 \mathrm{~cm}$; mase: $81.2 \pm 15.1 \mathrm{~kg} ;$ BMI: $23.3 \pm 1.2 \mathrm{~kg} / \mathrm{cm}^{2}$. TMG varijable su merene na BF mišiću tokom prelazne faze (polusezona i kraj sezone) treninga. Rezultati su pokazali da je prosečno Tc $-32.19 \pm 7.64 i$ $33.21 \pm 8.88 \mathrm{~ms}$, $\mathrm{Td}-25.56 \pm 3.58$ i $25.44 \pm 3.20 \mathrm{~ms}$, i Dm $-7.39 \pm 1.87$ i $7.52 \pm 2.50 \mathrm{~mm}$, za dominantnu i nedominantnu nogu, respektivno. Rezultati su pokazali da ne postoji statistički značajna razlika između ispitivanih TMG varijabli dominantne $i$ nedominantne noge (Wilks' lambda Value $=0.979, F=0.300, p=0.952$, Part. $\eta^{2}=0.021$ ). Kod zdravih vrhunskih fudbalera nema nikakvih razlika ispoljavanja neuromišićnih karakteristika BF bez obzira na dominantnost noge. Vrhunska utreniranost $u$ fudbalu $u$ sadejstvu sa potpuno zdravim statusom organizma $i$ lokomotornog aparata uslovljava i potpunu neuromišićno kontraktilnu simetričnost BF obe noge.

Ključne reči: tenziomiografija, fudbal, biceps femoris, mišić, dominantna noga 